\title{
Thermal Efficiency for Low Cost Houses using Translucent Water-Based Acrylic Paint
}

\author{
Kola O. Odeku \\ Kelvin O. Overen \\ Edson L. Meyer
}

Institute of Technology, University of Fort Hare, Alice, South Africa

\section{Doi:10.5901/mjss.2014.v5n20p2961}

\begin{abstract}
There are now different dimensions on how energy use in a house can be more efficient, sustainable and environmentally benign. In most houses, energy is consumed in its raw stage, in the form of fossil fuels which emit carbon dioxide causing global warming and climate change. Various scientific reports have indicated that inefficient energy consumption contribute to global climate change. International and national interventions are consistently advocating for responsible energy efficiency and renewable energy use in buildings. As part of thermal insulation, they also tacitly approved of any other means that would lead to efficient energy control and usage in buildings. This includes the use of thermal materials or combination of thermal materials to reduce the transfer of the inner space and the surrounding of the building. Against this backdrop, translucent water-based acrylic paint is a power means to provide thermal efficiency in houses. The paper also accentuates the importance of thermal efficiency for low cost houses using translucent water-based acrylic paint, especially in the rural remote areas of South Africa.
\end{abstract}

Keywords: Fossils fuels, Global climate Change, Acrylic paints, Thermal energy, energy efficiency, Low cost housing

\section{Introduction}

Thermal comfort in a house is as good as the worth of the house itself (Rawi et al. 2009). Scientifically, thermal comfort is achieved between indoor temperature of $20^{\circ} \mathrm{C}$ and $28^{\circ} \mathrm{C}$ while optimum relative humidity is between $30 \%$ and $60 \%$ (AlAjmi et al. 2006).Different proponents have come up with definitions of thermal comfort. According to Darby and White (2005:1), "an internationally-accepted definition of thermal comfort, used by ASHRAE is 'that condition of mind which expresses satisfaction with the thermal environment' (ISO7330). Perceptions of this environment are affected by air temperature, radiant temperature, relative humidity, air velocity, activity and clothing. An uncomfortable house as a result of abnormal temperature can impact on the health of the occupier and if care is not taken could lead to sudden death (Nicol andRudge, 2005).

The South African Building Code (SABC) recommends the indoor temperature range of $16^{\circ} \mathrm{C}$ to $28^{\circ} \mathrm{C}$ and relative humidity of 30\% to 60\% (Agrement, South Africa, 2002). As a result of the climatic condition in South Africa, more energy is consumed in heating system than cooling in order to achieve indoor thermal comfort (Philibert, 2005). Many of the Low Cost Houses $(\mathrm{LCH})$ were constructed without thermal efficiency considerations. Hence, the occupants find their home freezing in winter and overheating in summer, spending their limited resources to achieve thermal comfort (Holm et al, 2008). Majority of LCH occupants cannot afford electric heating systems or cooling appliance. Hence, occupants resort to using coal or paraffin for space heating, thus leading to the increase of carbon dioxide $\left(\mathrm{CO}_{2}\right)$ emissions which are hazardous to human health (Klunne, 2002).

Research works have extensively focused and concentrated on thermal comfort in the offices and huge buildings with only few research works on thermal comfort in the residential buildings. This has created a big gap in the thermal energy literature. It is against the backdrop of this scholarly gap that this paper makes a modest contribution to the scholarship by examining and analysing thermal efficiency for low cost houses in South Africa using translucent waterbased acrylic paint.

\section{Rationale of the Study}

The building codes and other guidelines for buildings clearly prescribed energy efficiency in buildings and houses (Iwaro 
and Mwasha, 2010). Compliance is mandatory and owners are compelled to ensure that their building plans conform to the energy efficiencies laws in South Africa (Laubscher, 2011). LCH are products of government housing intervention hence, they are designed by qualified engineers and as such the compliance with the codes and guidelines become mandatory. According to Al-Homoud (2008) "as climate modifiers, buildings are usually designed to shelter occupants and achieve thermal comfort in the occupied space backed up by mechanical heating and air-conditioning systems as necessary. Significant energy savings could be realized in buildings if they are properly designed and operated. As a least cost energy strategy, conservation should be supported in the energy future. For every unit of energy saved by a given measure of technology, resources will be saved, and the annual operating costs associated with producing that unit of energy will be reduced or eliminated. Therefore, architects can contribute to solving the energy problem if proper early design decisions are made regarding the selection and integration of building components. Thermal insulation is a major contributor and obvious practical and logical first step towards achieving energy efficiency, especially in envelope-load dominated buildings located in sites with harsh climatic conditions."

The codes and guidelines specifically, make provisions for all types of energy efficiencies interventions, and by inference this also includes the use of thermal efficiency for house using translucent water-based acrylic paint. In order to achieve thermal comfort, as part of efficient energy use in the house, thermal insulation from materials or combination of material used to resist the flow of heat due to their thermal properties becomes a useful tool to achieve and realise the comfort (Parsons, 2002). According to Al-Homoud, 2005. "insulation materials can be made in different forms including loose-fill form, blanket batt or roll form, rigid form, foamed in place, or reflective form. The choice of the proper insulation materials type and form depends on its application." This is the reason why translucent water-based acrylic paint becomes an aspect of materials that could be used to achieve energy efficiency in the LCH.

Heating and cooling loads of a house are mostly due to heat coming through the building envelope a (building envelope refers to those components of the building enclosing the habitable space from the building surrounding. These include walls, floor, roof, external doors and windows). From energy viewpoint, the most effective way of reducing heating and cooling loads is by applying thermal insulation to the building envelope (Ozel, 2011). Introducing energy efficient initiative will in future perfect the LCH already built and thus create a healthy home as well as minimize energy consumption for space heating which will eventually reduce the emission of greenhouse gases (Ming et al. 2014). This initiative is known as retrofitting. The introduction of the concept of retrofitting in LCH can be an immediate and long-term solution to the problem of housing and energy in South Africa (Klunne, 2003). This retrofit can be through retrofitting energy lighting in houses, through the use of photovoltaic system as the primary or secondary electricity source and improving thermal performance of the houses through thermal insulation.

\section{The Conceptual Explanations of Paints}

Paints are now increasingly becoming important aspects of mitigating temperature and reducing emissions in the house (Akadiri et al. 2012) due to their chemical compositions. (Berge, 2009). Due to different environmental problems, different chemicals are now being added to paints as solvents in order to tackle and mitigate the environmental problems (Schwarzenbach et al. 2005). Different types of solvents-paints ranging from "waterborne coatings, low-solvent coating, solvent-free powder coatings, and new radiation-curing coating systems with reactive solvents that are bound chemically during the hardening process were developed."(Freitag and Stoye, 2008). These environmental problem solving paints are becoming acceptable by building contractors because of their uniqueness in ensuring clean and friendly environment (Wenzel et al. 2000).

Paints are made of numerous components depending on the purpose for which they would be put to use. These components are classified into volatile and non-volatile. Volatile paints include organic solvents, water and coalescing agents (Freitag and Stoye, 2008). Non-volatile paints compose of binders, resins, plasticizers, paint additives, dyes pigments and extenders (Freitag and Stoye, 2008). Virtually all liquid paints have one function or another to fulfil when used. The most important component of paint is the binder because of its numerous characteristics which include resistance to weather (Brandt et al. 2010).

Paints are useful in many ways not just as stain resistance, but also as thermal comfort in a house (Pearson, 1998). "Paint with a high acrylic content will have much better water and stain resistance. Because of this stain resistance, a water-based glaze will not penetrate the base paint film and it will give you the best "open time" the glaze can offer." (Sickler and Dean, 2010). "Water-based glazes work best over paints and primers that have a large acrylic resin content; this is because of the "blocking" ability of a good acrylic paint. When you put a slow-drying glaze on top of a cheaper base paint, the paint re-opens and "grabs" on to the glaze making it difficult to remove and manipulate." (Sickler 
and Dean, 2010). The importance of acrylic paint is that, it is "a fast-drying paint containing pigment suspension in acrylic polymer emulsion."(Clark MD, Helmer BJ 2001). "Acrylic paints are water soluble, but become water-resistant when dry."(Miller et al. 1997). "In water based acrylics, the absorbers undergo decomposition during irradiation whereas the nanoparticles, by virtue of their inorganic nature are inherently stable." (Allen et al. 2002).

\section{Literature Review}

It is generally accepted that buildings consume a lot consumers of energy (Laustsen, 2008). In South Africa climate, where the winter is chilly and the summer hot, a substantial share of energy goes to heating up the buildings in winter and cooling $t$ them during summer. Al-Homoud (2005) points out that "this heating and air-conditioning load can be reduced through many means; notable among them is the proper design and selection of building envelope and its components."

Thermal regulation and insulation therefore become important in buildings not only to reduce energy used in making the building thermal comfortable, but also in reducing the annual energy cost ( Castleton et al. 2010). Undoubtedly, emissions are also being reduced as a result of the thermal regulation and insulation efficiency. Thermal insulation is therefore considered as an important factor in thermal comfort and sustainability in a building, in view of its immense benefits to the owner of the building and the environment (Al-Homoud, 2005).

As part of sustainable energy use and energy efficiency, regulating temperature using acrylic paint in a house serve as a temperature control mechanism. This in itself is a development of thermal energy storage systems because the paints stores and regulate heat and coal coming into the house and redistribute them in comfortable manners. It is also a viable energy savings mechanism, which in turn reduces the environment impact related to energy use." (Pasupathy et al. 2008). Inefficient and insufficient energy and the cost of buying them have triggered interest in all sorts of energy efficient devices and materials (Brown, 2001). Thermal energy therefore becomes a useful tool to store, redistribute and provide energy needs in a building in a sustainable way (Aitken, 2003).

As a result of integration of various energy sources into a system for heating and cooling the large mass of buildings which will react slowly to changes in heating/cooling demands, thermal energy storage is necessary (Deng et al. 2011). The thermal properties and the heat flow dynamics of a building determine the thermal performance of a building. Basically, heat is transferred by means of radiation, conduction and convection (Pasupathy et al. 2008). With respect to thermal energy of a building, heat from the sun gets to the surrounding of a building by means of radiation (AlHomoud, 2005). The heat is then transferred into the building through the building envelope (walls) by means of conduction ( Daouas, 2011). The heat is circulated around the house by convectional currents (Sanner et al. 2005). At night, a reverse process of conduction and convection takes place (Zhang, 2009). Warm air from one end of the house drift to a cold area, the walls at that area absorbs heat from the warm air and transfers to the building surrounding [Dilavore, 1984: 97]. This process continues until the indoor and outdoor temperature difference is at its minimum. According to the second law of thermal dynamics (entropy), heat will naturally flow from warmer side to cooler (Spengler, 2000). Since it is impossible to completely stop heat transfer, the best solution is to reduce the rate of heat transfer (Kreith et al. 2010).

In a building, the thickness of the wall and the difference between the inner and outer surface temperature of the wall impact and influence the rate of transfer of temperature. The rate of heat transfer will increase as the difference between the indoor and outdoor surface temperature increases. It can be reduced by increasing the thickness of the wall. To increase the thickness of the walls, a low thermal conductive material is required. Such material is known as thermal insulator. Insulation materials are selected based on their measure of the thermal resistance of a material. Therefore, the higher the value of a material the better its thermal insulation performance in the house.

There are two major groups of insulation materials; bulk and reflective insulation (or combine bulk and reflective) (Ito et al. 2011). Bulk insulation is design to resist heat transfer due to conduction and convection ((Kreith et al. 2010). Examples of bulk insulation are cellulose, fiber glass, mineral wool, extruded polystyrene foam (XPS), expanded polystyrene foam (EPS) or bead board and polyurethane foam. Reflective insulation on the other hand, resists radiant heat flow due to its high reflectivity and low emissivity (Erdem et al. 2014). A typical example of reflective insulation is aluminum foil [Downton and Reardon, 2010: 102]. Insulation materials are not restricted to these materials only. Other low thermal conductive materials are used as long as the primary aim of thermal insulation which is, increasing thermal resistance is achieved (Papadopoulos, 2005). 


\section{Case Study}

A LCH located at the Golf course settlement in Alice under the Nkonkobe Municipality Eastern Cape was used as a case study. Golf Course is located at $32^{\circ} \mathrm{S}$ latitude and $26^{\circ} \mathrm{E}$ longitude at an altitude of $493 \mathrm{~m}$; in the temperate interior (Zone 2) climate of South Africa (TIASA, 2010: 17). Golf Course has an average summer temperature of $18^{\circ} \mathrm{C}$ to $26^{\circ} \mathrm{C}$, with a relatively mild winter of an average temperature between $7^{\circ} \mathrm{C}$ to $20^{\circ} \mathrm{C}$. The east wind is predominant in summer while the winter is dominated by the west wind. A moderate wind speed of an average of $2.5 \mathrm{~m} / \mathrm{s}$ is experienced in Golf Course throughout the year. Like most LCH settlements in the country, Golf Course is a rural settlement primarily occupied by senior citizens, children and low income earners. As observed in the aerial photograph, some regions of the settlement are laid out with no particular consideration for geographical north. The house used is facing N16 ${ }^{\circ} \mathrm{E}$. It comprises of a bedroom, toilet and an open plan living room and kitchen. It has a floor dimension of $7.20 \mathrm{~m} \times 5.70 \mathrm{~m}$, giving an approximately area of $41 \mathrm{~m}^{2}$. The roof is made of galvanized corrugated iron sheets with no ceiling or any form of roof insulation. The walls of the buildings are made of the M6 $(0.39 \times 0.19 \times 0.14 \mathrm{~m})$ hollow concrete blocks, with no plaster or insulation. Thus, the thickness of the walls assumed the width $(0.14 \mathrm{~mm})$ of the blocks. More than $97 \%$ of the buildings in this settlement share the same design. The building façade (North wall) has two large $(1.10 \times 1.00 \mathrm{~m})$ windows. These windows allow the penetration of low angle winter sun rays into the building as well as the window in East wall, at the east elevation of the building; that provides access for the early morning sun rays.

Thermal mass is a term used to describe the thermal storage ability of building materials. Such materials absorb and store heat with low temperature change. When the air temperature around the thermal mass material drops, heat stored is released into the surrounding. Thermal mass is a function of the density and specific heat capacity of a material, the denser the material, the higher its thermal mass capacity (Gregory et al, 2007). For efficient use, thermal mass should be insulated from the external environment, i.e. it should be located within insulated walls (Victoria, 2005). The West wall in this case, has a low storage capacity due to the thickness and the material (hollow concrete block) used in the wall. Furthermore, it has a high heat absorption rate; since the wall is made of material of the same thermal properties. Therefore, when the outdoor air temperature drops; wall 3 absorbs and transfers heat from the inside of the building to the outside.

\section{The Intrinsic Role of Translucent Water-Based Acrylic Paint to Achieve Thermal Efficiency}

Government policies and building codes and guidelines prescribes and mandate the use of energy efficient devices and materials for all sorts of energy use in a LCH. Because of its effectiveness and efficiency in thermal comfort, translucent water-based acrylic paint is a good material for thermal efficiency and control in a house.

This is in line with the South African standard which was approved by the National Committee StanSA SC 5120.61K, Construction standards - Energy efficiency in buildings, in accordance with procedures of Standards South Africa, in compliance with annex 3 of the WTO/TBT agreement. Furthermore, it also meets the requirements of the Department of Energy in South Africa that introduced a Policy to support the Energy Efficiency and Demand Side Management Program for the Electricity Sector through the Standard Offer Incentive Scheme (EEDSMP, 2010). The scheme, in terms of Section 7(1) covers a whole range of buildings including private residential dwellings. These interventions are against the backdrop that South Africa is vulnerable to global climate change and has no strong adaptive capacity and as such energy efficiency using various devices, equipment and materials in buildings become more pressingly important.

\section{Conclusion}

The problem of emissions in houses can only be solved using various energy efficient devices and materials. As part of the solutions to the surge of global climate change, people living in $\mathrm{LCH}$ can get help by ensuring that there is thermal comfort in their homes through the use of translucent water-based acrylic paint which has proven to be efficient and environmental benign.

\section{Recommendations}

The desire to make living conditions interesting and comfortable is driving various initiatives and inventions. Global warming and climate change are realities that we need to face. Their devastating calamities and catastrophes are being 
experienced all over the world. Developing countries are the worst hit. This is the reason why leaders in these countries need to consider how energy is consumed. South Africa is one of the highest consumers of fossil fuels, but the remarkable thing about the country is that, through various interventions, it supports emissions reductions through research and administrative policies. The will to reduce emissions also underscores the government intervention that produced policy on energy efficiency and building codes to ensure that inefficient energy use in buildings is stopped and sanctioned at design stage. There is no room for complacency or unnecessary excuses, hence the involvement of all the role players. To achieve the objectives of emissions reduction of providing a safe and friendly environment through energy efficiency, all hands need to be on the deck to ensure compliance of energy efficiency in new green buildings and constructions. Monitoring and evaluation of the aspects of the codes and guidelines compelling energy efficiency should be carried out at all times. One of the materials that should be encouraged to be used, not only in LCHbut also in buildings generally, is the translucent water-based acrylic paint because of its value and characteristics in ensuring thermal comfort, energy saving and sustainable friendly environment. The deployment of this innovative breakthrough should be accelerated in all LCH in South Africa.

\section{Acknowledgements}

This work was commenced while the first author was a postdoctoral research fellow at the Institute looking at the policy on energy policy. The study of the second author compliments the work hence the collaboration and the substantive part of the scientific aspects was done by him. More importantly, the work benefited immensely from Eskom Tertiary Education Support Programme (TESP), South Africa under the auspices of Fort Hare Institute of Technology, University of Fort Hare, Alice, Eastern Cape, South Africa.

\section{References}

Aitken DW 2003. Transitioning to a renewable energy future.- ISES White Paper. From http://energycrisis.org/apollo2/ises/ises_wp_ 200409.pdf. (Retrieved on 2 November, 2012).

Akadiri PO, EA Chinyio, PO Olomolaiye 2012. Design of a sustainable building: A conceptual framework for implementing sustainability in the building sector. From http://www.mdpi.com/2075-5309/2/2/126/htm. (Retrieved on 24 March, 2012).

Al-Ajmi F, Loveday DL, Hanby VI 2006. The cooling potential of earth-air heat exchangers for domestic buildings in a desert climate. Building and Environment. 41(3): 235-244.

Al-Homoud MS 2005.Performance characteristics and practical applications of common building thermal insulation materials. Building and Environment. 40(3): 353-366.

Allen NS, Edge M, Ortega A, Liauw CM, Stratton J, McIntyre RB 2002. Behaviour of nanoparticle (ultrafine) titanium dioxide pigments and stabilisers on the photooxidative stability of water based acrylic and isocyanate based acrylic coatings. Berge B 2009. The ecology of building materials. Architectural Press, Massachutes, USA.

Blumenfeld J 1997. From Icon to Scapegoat: The Experience of South Africa's Reconstruction and Development Programme. Development Policy Review. 15(1): 65-91.

Brandt A, Milne A, Weyers H 2010. Paints and Coatings, 9. Application http://onlinelibrary.wiley.com/doi/10.1002/14356007 .018 008/abstract?deniedAccessCustomisedMessage=\&userlsAuthenticated=false. (Retrieved on 19 September, 2012).

Brown MA 2001. Market failures and barriers as a basis for clean energy policies. Energy Policy, 29(14): 1197-1207. (Retrieved on 20 July, 2012).

Castleton HF, Stovin V, Beck SBM, Davison JB 2010. Green roofs; building energy savings and the potential for retrofit. Energy and Buildings. 42(10): 1582-1591.

Clark MD, Helmer BJ 2001. Acrylic modified waterborne alkyd dispersions. From http://www.google.com/patents/US6242528. (Retrieved on 25 July, 2012).

Cuce E, Cuce PM, Wood CJ, Riffat SB 2014. Toward aerogel based thermal superinsulation in buildings: A comprehensive review. Renewable and Sustainable Energy Reviews. 34: 273-299.

Daouas N 2011. A study on optimum insulation thickness in walls and energy savings in Tunisian buildings based on analytical calculation of cooling and heating transmission loads. Applied Energy. 88(1): 156-164.

Darby S, White R 2005. Thermal comfort. Background document C for the 40\% House report, Environmental Change Institute. University of Oxford.

Deng J, R.Z. Wang, G.Y. Han 2011. A review of thermally activated cooling technologies for combined cooling, heating and power systems. Progress in Energy and Combustion Science. 37(2): 172-203.

du Plessis C, Irurah D, Scholes RJ 2003. The built environment and climate change in South Africa. Building Research \& Information. 31(3-4): 240-256.

Dundean S. What is latex and acrylic paint? From www.dundean.com/tips_what_is_latex_paint.shtml. (Retrieved on $15 \mathrm{March}, 2012$ ).

Freitag W, Stoye D 2008. Paints, coatings and solvents. Wiley-VCH, New York, USA. 
Geller H, Harrington P, Rosenfeld AH, Tanishima S, Unander F 2006. Polices for increasing energy efficiency: Thirty years of experience in OECD countries. Energy Policy. 34(5): 556-573.

Gilbert A 2004. Helping the poor through housing subsidies: lessons from Chile, Colombia and South Africa. Habitat International. 28(1): 13-40.Gregory K, Moghtaderi B, Sugo H, Page A, (2007) Effect of Thermal mass on The Thermal Performance of Various Australian Constructions Systems, April, p. 459-3.

Ineichen B 2003. Homes and Health: How housing and health interact. E\&FN Spon, London, UK.

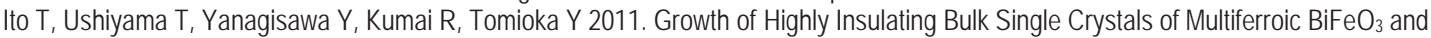
Their Inherent Internal Strains in the Domain-Switching Process. Crystal. Growth Design 11: 5139-5143.

Iwaro J, Mwasha A 2010. Implications of building energy standard for sustainable energy efficient design in buildings. International Journal on Energy Environment. From http://scholar.google.co.za/scholar?q \&btnG=\&hl=en\&as_sdt=0\%2C5. (Retrieved on 2 May, 2013).

Klunne W E 2003. Energy use for space heating in RDP houses, January, p. 3.

Kreith F R, Bohn MM 2010. Principles of heat transfer. Cengage Learning, Stamford, USA.

Laubscher J 2011. An investigation of the National Building Regulations to promote uniformity and sustainability in the South African built environment. From http://www.repository.up.ac.za/handle/2263/28660. (Retrieved on 2 August, 2012).

Laustsen J 2008. Energy efficiency requirements in building codes, energy efficiency policies for new buildings. International Energy Agency.From energie-cluster.ch. http://www.energie-cluster.ch/ecweb5/de/wissenstransfer/innovationsgruppen/ig-peg/forschungund-entwicklung/efficient_buildings_iea_2008.pdf. (Retrieved on 29 July, 2012).

Lomas KJ, Kane T K, 2013. Summertime temperatures and thermal comfort in UK homes. Building Research \& Information. 41(3): pages 259-280.

Lombard C, E.H Mathews, M Kleingeld 1999. Demand-Side Management through thermal efficiency in South African houses. Energy and Buildings. 29(3): 229-239.

Miller BA, Rose GD, Schmidt DL 1997. Reversible and irreversible water-based coatings. US Patent 5,674,934. From http://www.google.com/patents/US5674934. (Retrieved on 25 October, 2012).

Ming T, de_Richter R, Liu W, Caillol S 2014. Fighting global warming by climate engineering: Is the Earth radiation management and the solar radiation management any option for fighting climate change? Renewable and Sustainable Energy Reviews. 31: $792-834$.

Mthiyane FS 2008. Electrical energy efficiency awareness by poor communities in South Africa and its impact on their energy needs. From https://scholar.sun.ac.za/handle/10019.1/817. (Retrieved on 23 April, 2012).

Nicol F, Rudge J 2005. Cutting the cost of cold: affordable warmth for healthier homes. E \& FN Spon, London, UK.

Ozel M 2011. Effect of wall orientation on the optimum insulation thickness by using a dynamic method, p. 2429.

Papadopoulos AM 2005. State of the art in thermal insulation materials and aims for future developments. Energy and Buildings. 37(1): $77-86$.

Parsons K 2002. Human thermal environments: the effects of hot, moderate, and cold environments on human health, comfort and performance. Talor \& Francis, New York, USA.

Pasupathy A, R. Velraj, R.V. Seeniraj 2008.Phase change material-based building architecture for thermal management in residential and commercial establishments. , Renewable and Sustainable Energy Reviews. Volume 12, Issue 1, January 2008, Pages 3964.

Pearson D 1998. The new natural house book: Creating a healthy, harmonious, and ecologically sound home. Fireside, New York, USA.

Philibert C 2005. The present and future use of solar thermal energy as a primary source of energy. From http://www. interacademycouncil.net/ Object.File/Draft/10/360/0.pdf. (Retrieved on 17 May, 2012).

Polymer Degradation and Stability. 78(3): 467-478.

Rawi M, SeNSe L, Al-Anbuky A. 2009. Passive House sensor networks: Human centric thermal comfort concept. From http://scholar.google.co.za/scholar?q=iPassive+House+sensor+networks\%3A+Human+centric+thermal+comfort+concept\&btnG= \&hl=en\&as_sdt=0\%2C5. (Retrieved on 17 March, 2012).

Sanner B, G Hellström, J Spitler 2005. Thermal response test-current status and world-wide application. From http://sanneronline.de/media/1436.pdf. (Retrieved on 16 August, 2012).

Schwarzenbach RP, Gschwend PM, Imboden DM 2005. Environmental organic chemistry. John Wiley \$ Sons, New Jersey, USA.

Sickler D, Dean SE 2010. The Keys to Color: A Decorator's Handbook for Coloring Paints, Plasters and Glazes. From http://books.google.co.za/books?hl=en\&lr=\&id=NIIZKubiXGQC\&oi=fnd\&pg=PP11\&dq=. (Retrieved on 15 February, 2012).

Spengler JD 2000. Indoor Air Quality Factors in Designing A Healthy Building. Annual Review of Energy and the Environment. 25:567600.

Swanepoel L 2001. Master of advanced studies in landscape architecture (masla) in the faculty of graduate studies. From http://scholar.google.co.za/scholar?q=. (Retrieved on 10 November, 2012).

TIASA, 2010. Thermal Insulation Association of South Africa Thermal insulation-the invisible energy saver: The Guide to Energy Efficient Thermal Insulation Buildings, Midrand: AAAMSA administered.

Wenzel H, MZ Hauschild, L Alting 2000. Environmental Assessment of Products: Volume 1: Methodology, tools and case studies in product development. Kluwer Academic Pubishers, Massachuttes, USA.

Zhang J 2009. Investigation of airflow and heat transfer in earth-to-air heat exchnagers. From http://spectrum.library. concordia.ca/976422/. (Retrieved on 10 October, 2012). 